\title{
Synthesis, Characterization and Antimicrobial Evaluation of some Schiff Bases Derived from Symmetrical 4-amino-1,2,4-triazole
}

\author{
Badie A. Ahmed \\ Salim J. Mohammed \\ Bassam T. Khalil \\ Department of Chemistry \\ College of Science \\ University of Mosul
}

(Received 6/2/2013; Accepted 8/4/2013)

\begin{abstract}
A series of new Schiff bases, namely 4-(substituted benzylidene amino)-4H-1,2,4triazoles $(5 \mathrm{a}-\mathrm{j})$ derivatives were synthesized by the reaction of symmetrical substituted 4amino-1,2,4-triazole (4) and appropriate substituted aromatic aldehydes in presence of acetic acid. The synthesized imines were characterized on the bases of their physical properties and spectroscopic data. Some of these compounds were tested for biological activities as antibacterial and antifungal agents and showed a significance to moderate activity.
\end{abstract}

Keywords: Heterocyclic, 1,2,4-triazole, schiff bases, biological activity.

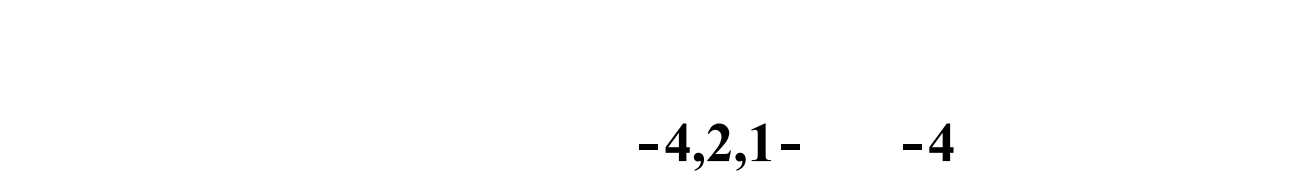

\section{الملغ}

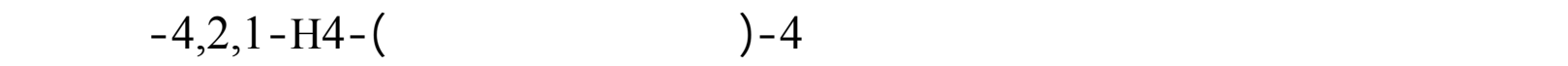
(5a-j)

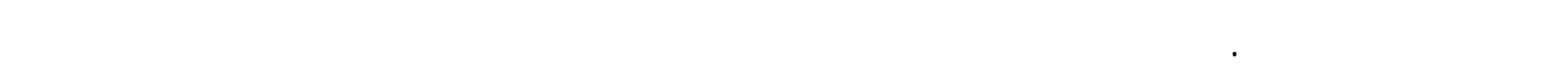

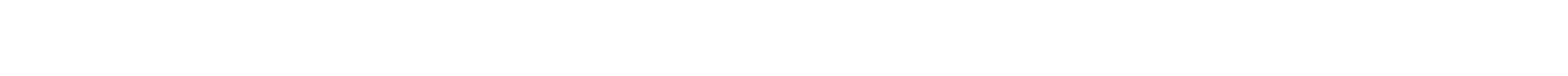
بعضها ومتوسطة في بعضها الآخر.

\section{INTRODUCTION}

Among five membered heterocyclics, triazoles represent a class of compounds of a great importance in biological chemistry. Owing to their useful bioactivities, increasing attention has been focused on this ring system. For instance, substituted 1,2,4-triazole possesses various biological activities such as antifungal (Serdar et al., 2007), antimicrobial (El-Sayed, 2006), antitumor (Elise, 1993), weed killer agent (Mori and Iwasaki, 1995) and anti-oxidant (Muhammad et al., 2012). 
Substituted 1,2,4-triazoles are of great utility in synthetic organic chemistry, as a consequence, various methods have been used and described in the literature (Bentiss et al., 2000), (klingele and Sally, 2003), (Cheng et al., 2007) (Sudeep et al., 2010). Imine derivatives (Schiff bases) are a supreme type of organic compounds containing a carbonnitrogen double bond which could be synthesized by a direct condensation of aldehydes or ketones with primary amines (Ashraf et al., 2011). Schiff bases are versatile intermediate in the synthesis of heterocyclic compounds (Jae-Chul and Oee-Sook, 2009). In pharmaceutical filed (Sharma, 2011), imines derivatives are reported to show a variety of biological activities such as antibacterial (Naser et al., 2010), (Rajaa, 2008). Some of 1,2,4-triazole Schiff bases are used as analgesic and anti-inflammatory agents (Chendramouli et al., 2012).

In view of these facts and as a continuation of our search for new biological agents, in this paper we report, the synthesis of new Schiff bases by the reaction of new 4-amino-3,5bis(diphenyl hydroxymethyl)-1,2,4-triazole with different aromatic aldehydes in hot acetic acid.Some of theme were evalutated for their biological activities.

\section{EXPERIMENTAL}

Melting points were measured on an electro thermal 9300 melting point apparatus and are uncorrected. IR spectra were recorded on a Bruker optics (FT-IR) spectrophotometer Co. using $\mathrm{KBr}$-disk. ${ }^{1} \mathrm{H}-\mathrm{NMR}$ and ${ }^{13} \mathrm{C}-\mathrm{NMR}$ spectra were recorded on Bruker $300-\mathrm{MHz}$ spectrometer (University of Al Al-Bait Jordan) using TMS as an internal standard and DMSO- $\mathrm{d}_{6}$ as a solvent. UV spectra were recorded by Shimadzu UV-Visible recording UV160 spectrophotometer. The methyl benzilate (2) (m.p.76 ${ }^{\circ} \mathrm{C}$ ) and benzilic acid hydrazide (3) (m.p.166-167 ${ }^{\circ} \mathrm{C}$ ) were prepared by (Mohammed, 2000). The theoretical calculation and three dimensional (3D) configurations were achived out using (Chem Office Program, Version 8.0.3 September 24, 2003 MOPAC/MM2. For determination of the preliminary biological activities the disc diffusion method was used (Bauer et al.,1966; Lu et al., 2005).

\section{Prepration of 4-amino-3,5-bis(diphenyl hydroxy methyl)-1,2,4-triazole (4):}

Benzilic acid hydrazide (3) (0.968 g, 0.004 mole) was dissolved in (10ml) dimethyl sulfoxide, the mixture was refluxed for $(17 \mathrm{~h}$.) , then distilled under a reduced pressure, cooled, then $(10 \mathrm{ml})$ of water was added. The reaction mixture was stirred at room temperature for $(12 \mathrm{~h}$.), The resulting solid was filtered, dried and recrystallized from aqueous ethanol to give the corresponding compound (4) as a pale yellow powder $(1.07 \mathrm{~g}$, $60 \%$ ) (m.p. $\left.140-142^{\circ} \mathrm{C}\right)$

\section{Preparation of 4-(substituted benzylidine amino)-4H-3,5-bis(diphenyl hydroxy methyl) -1,2,4-triazole (5a-j) (Serdar et al., 2007): General Procedure:}

A solution of 4-amino-3,5-bis(diphenyl hydroxy methyl)-1,2,4-triazole (4) (0.001 mole, $0.448 \mathrm{gm})$ in $(10 \mathrm{ml})$ acetic acid was refluxed with an appropriate aromatic aldehyde ( 0.001 mole) for $(6 \mathrm{hrs})$. The reaction mixture was poured into ice-water with stirring, the precipitated product was filtered off, and washed with water, dried to give a solid product and recrystallized from suitable solvent. The physical and spectral data are listed in (Tables 1 and 2) respectively. 
Antimicrobial studies: (Bauer et al., 1966; Lu et al., 2005).

Disc diffusion method (sensitivity test) was adopted for this study following the published procedure. It is worth mentioning that the incubation time for bacterial activity test was 24 hrs., while the antifungal test was 14 days. The results of these studies are tabulated in Tables (4) and (5).

Table 1: Physical data for compounds (5a-j):

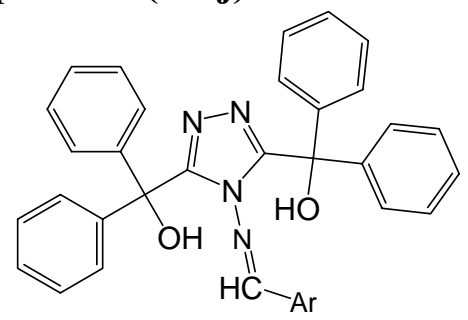

\begin{tabular}{|c|c|c|c|c|c|}
\hline $\begin{array}{c}\text { Compd. } \\
\text { No. }\end{array}$ & $\mathbf{A r}$ & M.P. $\left({ }^{\circ} \mathbf{C}\right)$ & $\begin{array}{c}\text { Yield } \\
(\%)\end{array}$ & Color & $\begin{array}{c}\text { Crystallization } \\
\text { solvent }\end{array}$ \\
\hline $5 \mathrm{a}$ & $\mathrm{C}_{6} \mathrm{H}_{5}$ & $136-138$ & 61 & brown & Ethanol: water \\
\hline $5 \mathrm{~b}$ & $\mathrm{p}-\mathrm{OCH}_{3} \mathrm{C}_{6} \mathrm{H}_{4}$ & $161-163$ & 78 & brown & Ethanol \\
\hline $5 \mathrm{c}$ & ${\mathrm{p}-\mathrm{CH}_{3} \mathrm{C}_{6} \mathrm{H}_{4}}$ & $182-184$ & 59 & pale yellow & Ethanol: water \\
\hline $5 \mathrm{~d}$ & $\mathrm{p}-\mathrm{NO}_{2} \mathrm{C}_{6} \mathrm{H}_{4}$ & $109-110$ & 90 & orange & Ethanol \\
\hline $5 \mathrm{e}$ & $\mathrm{o}-\mathrm{ClC}_{6} \mathrm{H}_{4}$ & $171-173$ & 75 & orange & Ethanol \\
\hline $5 \mathrm{f}$ & $2,4-\mathrm{di} \mathrm{ClC}_{6} \mathrm{H}_{3}$ & $268-270$ & 65 & light brown & Methanol \\
\hline $5 \mathrm{~g}$ & $\begin{array}{c}3,4 \mathrm{di}_{-} \\
\mathrm{OCH}\end{array} \mathrm{C}_{6} \mathrm{H}_{3}$ & $131-133$ & 40 & dark brown & Ethanol: water \\
\hline $5 \mathrm{~h}$ & $\begin{array}{c}4-\mathrm{OH}-3- \\
\text { OCH }\end{array} \mathrm{C}_{6} \mathrm{H}_{3}$ & $191-193$ & 62 & pale yellow & Methanol \\
\hline $5 \mathrm{i}$ & $4-\mathrm{Piperonyl}$ & $219-221$ & 46 & brown & Ethanol \\
\hline $5 \mathrm{j}$ & $2-$ thiophenyl & $238-240$ & 37 & pale brown & Ethanol: water \\
\hline
\end{tabular}

\section{RESULTS AND DISCUSSION}

Keeping in view the biological activity and medical importance of triazoles and Schiff bases, we synthesized 4-amino-3,5-bis(diphenyl hydroxymethyl)-1,2,4-triazole (4) and have utilized it as a synthone for the synthesis of various new Schiff bases, which readily undergo condensation with a variety of aromatic aldehydes. Benzilic acid (1) was converted to methyl benzilate (2) by reaction with methanol. The ester was treated with hydrazine hydrate in ethanol to afford benzilic acid hydrazide (3) (Mohammed, 2000). The acid hydrazide (3) was transformed to the 4-amino-3,5-bis(diphenyl hydroxymethyl)-1,2,4triazole (4) by refluxing with dimethyl sulfoxide (scheme 1). The IR spectrum of the triazole (4) showed broad bands of $(\mathrm{OH})$ group at $\left(3410 \mathrm{~cm}^{-1}\right),\left(\mathrm{NH}_{2}\right)$ group at $\left(3306 \mathrm{~cm}^{-1}\right)$ and a band of $(\mathrm{C}=\mathrm{N})$ group at $\left(1651 \mathrm{~cm}^{-1}\right)$. The UV spectrum showed $\lambda_{\max }\left(\mathrm{CHCl}_{3}\right)$ at $(318 \mathrm{~nm})$ due to $\left(\pi \rightarrow \pi^{*}\right)$ transition. This assignment was further supported by ${ }^{1} \mathrm{H}-\mathrm{NMR}$ spectrum data which showed multiplet bands at $\delta(7.05-7.93 \mathrm{ppm})$ for $(20 \mathrm{H})$ aromatic 
Badie A. Ahmed et al.,

protons, a singlet bands at $(4.51 \mathrm{ppm})$ for two $(\mathrm{OH})$ protons and broad band at (1.20 ppm) for two $\left(\mathrm{NH}_{2}\right)$ protons.<smiles>COC(=O)C(O)(c1ccccc1)c1ccccc1</smiles>

(1)<smiles>COC(=O)C(O)(c1ccccc1)c1ccccc1</smiles>

(2)

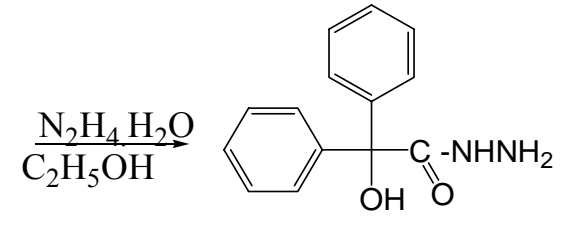

(3)

DMSO

Reflux,17hrs.

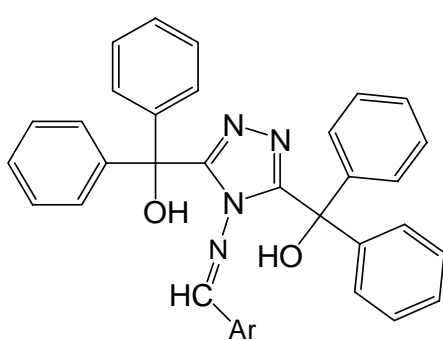

$(5 \mathrm{a}-\mathrm{j})$

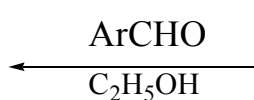

(4)

$\mathrm{R}=\mathrm{a}: \mathrm{C}_{6} \mathrm{H}_{5}, \mathrm{~b}: 4-\mathrm{CH}_{3} \mathrm{OC}_{6} \mathrm{H}_{4}, \mathrm{c}: 4-\mathrm{CH}_{3} \mathrm{C}_{6} \mathrm{H}_{4}, \mathrm{~d}: 4-\mathrm{NO}_{2} \mathrm{C}_{6} \mathrm{H}_{4}$, e: $2-\mathrm{ClC}_{6} \mathrm{H}_{4}$,

f :2,4-di $\mathrm{ClC}_{6} \mathrm{H}_{3}$, g: 3,4-di- $\mathrm{CH}_{3} \mathrm{OC}_{6} \mathrm{H}_{3}$, h: 4-OH -3 - $\mathrm{CH}_{3} \mathrm{OC}_{6} \mathrm{H}_{3}$, i: 4-Piperonyl, j: 2-thiophenyl.

(Scheme)

The compound (4) was then treated with some aromatic aldehydes to give a series of new Schiff bases derivatives (5a-j). The structure of all new compounds has been elucidated by IR, UV, ${ }^{1} \mathrm{H}-\mathrm{NMR},{ }^{13} \mathrm{C}-\mathrm{NMR}$ spectra,IR spectra(table2) showed the following stretching bands; $\left(1616-1676 \mathrm{~cm}^{-1}\right)$ due to the $(\mathrm{C}=\mathrm{N})$ bond, $\left(3025-3061 \mathrm{~cm}^{-1}\right)$ for the $(=\mathrm{C}-\mathrm{H})$ bond and at $\left(3250-3255 \mathrm{~cm}^{-1}\right)$ for the $(\mathrm{O}-\mathrm{H})$ bond. The UV spectra of compounds $(5 \mathrm{a}-\mathrm{j})$ showed $\lambda_{\max }$ $\left(\mathrm{CHCl}_{3}\right)$ Table (2) at the range $(269-340 \mathrm{~nm})$ due to $\left(\pi \rightarrow \pi^{*}\right)$ electronic transition. The ${ }^{1} \mathrm{H}-$ NMR spectra studies of compounds (5d and 5e) exhibited a multiplet bands at (7.60-6.90 $\mathrm{ppm}, 6.82-7.51 \mathrm{ppm})$ due to aromatic protons, broad bands at (4.51 ppm, $4.45 \mathrm{ppm})$ due to $(\mathrm{OH})$ protons and a singlet band at $(6.53 \mathrm{ppm}, 6.31 \mathrm{ppm})$ due to $(\mathrm{HC}=\mathrm{N})$ protons.

Table 2: IR and UV. spectral data for compounds (5a-j)

\begin{tabular}{|c|c|c|c|c|}
\hline \multirow{2}{*}{ Compd. No. } & \multicolumn{3}{|c|}{ IR $(\mathrm{KBr}) v \mathrm{~cm}^{-1}$} & \multirow{2}{*}{$\begin{array}{c}\mathbf{U V} \\
\lambda_{\max } \mathbf{n m} \\
\left(\mathrm{CHCl}_{3}\right)\end{array}$} \\
\hline & O-H & $=\mathrm{C}-\mathrm{H}$ & $\mathbf{C}=\mathbf{N}$ & \\
\hline $5 a$ & 3275 & 3059 & 1662 & 269 \\
\hline $5 b$ & 3272 & 3057 & 1653 & 324 \\
\hline $5 c$ & 3300 & 3025 & 1652 & 316 \\
\hline $5 d$ & 3255 & 3057 & 1647 & 340 \\
\hline $5 e$ & 3270 & 3061 & 1616 & 328 \\
\hline $5 f$ & 3206 & 3061 & 1616 & 322 \\
\hline $5 \mathrm{~g}$ & 3261 & 3057 & 1617 & 316 \\
\hline $5 \mathrm{~h}$ & 3321 & 3057 & 1676 & 334 \\
\hline $5 \mathrm{i}$ & 3350 & 3029 & 1653 & 318 \\
\hline $5 \mathrm{j}$ & 3270 & 3057 & 1653 & 326 \\
\hline
\end{tabular}


Table 3: ${ }^{1} \mathrm{H}-\mathrm{NMR}$ and ${ }^{13} \mathrm{C}-\mathrm{NMR}$ data for compounds (5d and $5 \mathrm{e}$ )

\begin{tabular}{|c|c|c|}
\hline Compd. No. & $\begin{array}{c}\mathbf{1}^{\text {H-NMR ppm, }} \\
\text { DMSO-d }\end{array}$ & $\begin{array}{c}\mathbf{1 3}_{\mathbf{6}} \mathbf{C - N M R ~ p p m , ~} \\
\text { DMSO-d }_{\mathbf{6}}\end{array}$ \\
\hline \multirow{2}{*}{$5 \mathrm{~d}$} & $4.51(\mathrm{bs}, 2 \mathrm{H}, \mathrm{OH}) ; 6.53(\mathrm{~s}, 1 \mathrm{H}$, & $87.8,122,127,127.4-127.7$, \\
& $\mathrm{HC}=\mathrm{N}) ; 6.90-7.60(\mathrm{~m}, 24 \mathrm{H}, \mathrm{ArH})$ & $138,142,151,157,170$ \\
\hline \multirow{2}{*}{$5 \mathrm{e}$} & $4.45(\mathrm{bs}, 2 \mathrm{H}, \mathrm{OH}) ; 6.31(\mathrm{~s}, 1 \mathrm{H}$, & $80,127.4-131.4,133-134$, \\
& $\mathrm{HC}=\mathrm{N}) ; 6.82-7.51(\mathrm{~m}, 24 \mathrm{H}, \mathrm{ArH})$ & 153,167 \\
\hline
\end{tabular}

\section{Antibacterial and antifungal studies}

\section{BIOLOGICAL ACTIVITY}

All the synthesized compounds were screened for in vitro antibacterial and antifungal activity by adopting the disc diffusion method. For antibacterial studies the microorganisms employed were Esherichia coli, Staphylococcus aurous, Micrococcus, Pseudomonas, Bacillius 11 and Bacillius 12. While for antifungal, Microsporumgypseum, Microsporumdestortum, and Trichophytonrubrum were used as microorganisms. Both antimicrobial studies were assessed by a minimum inhibitory concentration. The results are summarized in Tables (4 and 5).

From the obtained data, it is evident that compounds (5a and $5 \mathrm{~d}$ ) possess a very good activity against bacteria Strains like E. coli and Staphylococcus. And the compounds (5h, 5i and 5j) possess almost a significant activity against all fungi tested at $1 \mathrm{mg} / \mathrm{ml}$ and $2 \mathrm{mg} / \mathrm{ml}$. The remaining compounds showed a moderate activity against other bacteria and fungi tested.

Table 4: Antibacterial activity of (5a-j) compounds

\begin{tabular}{|c|c|c|c|c|c|c|}
\hline $\begin{array}{c}\text { Compds. } \\
\text { No. }\end{array}$ & \multicolumn{7}{|c|}{ Inhibition zone"\%" (mm) } \\
\cline { 2 - 7 } & E. coli & $\begin{array}{c}\text { Staphylococcus } \\
\text { aurous }\end{array}$ & Micrococcus & Pseudomonas & Bacillius 11 & Bacillius12 \\
\hline $5 \mathrm{a}$ & 17 & 11 & ------- & ------- & ------- & -------- \\
\hline $5 \mathrm{~b}$ & 8 & 10 & ------- & ------ & ------- & ------- \\
\hline $5 \mathrm{c}$ & ------ & ------- & 9 & 6 & 6 & 6 \\
\hline $5 \mathrm{~d}$ & 6 & 17 & ------- & ------ & ------- & ------- \\
\hline $5 \mathrm{e}$ & ------ & ------- & 6 & 6 & 6 & 6 \\
\hline $5 \mathrm{f}$ & 9 & 6 & ------- & ------ & ------- & ------- \\
\hline $5 \mathrm{~g}$ & 9 & 11 & ------- & ------- & ------- & ------- \\
\hline $5 \mathrm{~h}$ & ------ & ------- & 6 & 6 & 6 & 6 \\
\hline $5 \mathrm{i}$ & ------ & ------- & 6 & 6 & 6 & 6 \\
\hline $5 \mathrm{j}$ & 9 & 6 & ------ & ------ & ------- & ------- \\
\hline
\end{tabular}

Inhibition zone diameter (mm) (\% inhibition): 6-10 (27-45\%); 10-14 (45-64\%); $14-18$ (64-82\%); 18-22 (82$100 \%)$. 
Table 5: Antifungal activity of some selected compounds

\begin{tabular}{|c|c|c|c|c|c|c|}
\hline \multirow{2}{*}{$\begin{array}{c}\text { Compds. } \\
\text { No. }\end{array}$} & \multicolumn{2}{|c|}{$\begin{array}{c}\text { Microsporumgypseum } \\
\text { (cm) }\end{array}$} & $\begin{array}{c}\text { Microsporumdestortum } \\
\text { (cm) }\end{array}$ & \multicolumn{2}{c|}{$\begin{array}{c}\text { Trichophytonrubrum } \\
\text { (cm) }\end{array}$} \\
\cline { 2 - 7 } & $\mathbf{1 m g / m l}$ & $\mathbf{2 m g / m l}$ & $\mathbf{1 m g / m l}$ & $\mathbf{2 m g / m l}$ & $\mathbf{1 m g / m l}$ & $\mathbf{2 m g / m l}$ \\
\hline $5 \mathrm{~h}$ & 0.3 & zero & 1.5 & zero & 0.2 & zero \\
\hline $5 \mathrm{i}$ & 1.2 & 0.3 & 1.4 & 0.1 & 1.3 & zero \\
\hline $5 \mathrm{j}$ & 1.5 & zero & 2.5 & zero & 2 & zero \\
\hline
\end{tabular}

Inhibition zone diameter (cm) (\% inhibition): 5.5-3.3 (0-40\%); 3.3-2.2 (40-60\%); 2.2-1.1 (60-80\%); 1.1- zero $(80-100 \%)$.

In conclusion, we have synthesized a new symmetrical 3,5-disubstituted-4-amino-1,2,4triazole (4) and a series of new Schiff bases (5a-j). These compounds are stable compounds, which renders them beneficial substances for antimicrobial activities.

\section{ACKNOWLEDGEMENTS}

Authors are thankful to Department of Chemistry, College of Science for the facilities given to perform this work. Thanks are also to Dr. Maha A. Al-Rejaboo, Department of Biology, College of Science, University of Mosul for the biological assay.

\section{REFERENCES}

Ashraf, M.A.; Mahmood, K.; Abdul Wajid, (2011). Synthesis, Characterization and Biological Activity of Schiff Bases. International Conference on Chemistry and Chemical Process, Iacsae press, Singapore, 10, 1-7.

Bauer, A.W.; Kirby, W.A.M.; Sherris, J.S.; Turk, M. (1966). Antibiotic susceptibility testing by a standardized single disc method. Am. J. Clin. Pathol., 45, 493-496.

Bentiss, F.; Michel, L.; Didier, B. (2000). Accelerated synthesis of 3,5- disubstituted 4-amino-1,2,4-triazol. Tetrhedron. Letters., 41, 1539-1541.

Chandramouli, M.R.; Shivan, Th.B.; Nayanbhai, B.; Udupi, R.H. (2012). Synthesis and biological screening of certain new triazole Schiff bases and their derivatives bearing substituted benzothiazole moiety. J. Chem. Pharm. Rese., 4(2), 1151-1159.

Cheng, L.; Wei-Xiong, Z.; Bao-Hui, Y.; Jian-Bin, L.; Xiao-Ming, (2007). In situ. solvothermal generation of 1,2,4-triazolates and related compounds from organonitrile and hydrazine hydrate. A Mechanism Study, Inorganic Che. Articals. 46, 1135-1143.

EL-Sayed, R. (2006). Synthesis, antibacterial and surface activity of 1,2,4-triazole derivatives. Indian J. Chem., 45B, 738-74.

Elisc, C. (1993). Carboxyamido triazole (CAI) as anticancer drug. Science News, $143,255$.

Jae-Chul, J.; Oee-Sook, P. (2009). Synthetic Approaches and biological activities of 4-hydroxycoumarin derivatives. Molecules. 14, 4790-4803. 
Klingele, M.H.; Sally, B. (2003). The coordination chemistry of 4-substituted-3,5- di (2pyridyl)-4H-1,2,4-triazoles and related ligands. Coordination Chem. Reviews. 241, 119-132.

Lu, L.; Chen, Y.; Chou, Ch. (2005). Antibacterial activity of propolis against staphylococcus aureus. Inter J. Food Microbiology. 102, 213-220.

Mohammed, S.J. (2000). Synthesis of new expected biologically active five-membered heterocyclic compounds derived from benzilic acid hydrazide. Ph. D. thesis, University of Mosul, Iraq.

Mori, I.; Iwasaki G. (1995). Synthesis of inhibitors of imidazole glycol phosphate. J. Am. Chem. Soc., 117, 4411-4416.

Muhammad, H.; Muhammad, S.; Muhammad, T.H.; Nasim, H.R.; Sumera, Z.; Muhammad, A.M.; Aslam, P.G.J.; Jamshed, I. (2012). Synthesis, Urease Inhibition, Antioxidant and Antibacterial Studies of Some 4-Amino-5-aryl-3H1,2,4-triazole-3-thiones and their 3,6-Disubstituted 1,2,4- Triazolo [3,4-b]-1,3,4thiadiazole derivatives. J. Braz. Chem. Soc., 23(5), 854- 860.

Naser, A.W.; Hassan, T.G.; Abid Allah, M.A. (2010). Synthesis and characterization of new azo-Schiff bases and study biological activity of some these compounds. $J$. University of Anbar for Pure Science. 4(3), 1-5.

Rajaa, A.G. (2008). Preparation and characterization of new azo-schiff bases and studying of its biological activity. M.Sc. thesis, University of Kufa, Iraq.

Sharma, V.; Birendra, S.; Rakesh, B.; Mukesh, B.; Rakhi, Kh.; Jyoti, A. (2011). Exploring Potential of 1, 2, 4-triazole: a brief review. Pharmacologyonline. 1, 1192-1222.

Serdar, M.; Nurhan, G.; Sengul, A.K.; Neslihan, D. (2007). Synthesis of some novel 3,5diaryl-1,2,4-triazole derivatives and investigation of their antimicrobial activities. Turk. J. Chem., 31, 315-326.

Sudeep, M.; Dibyajyoti, S.; Vibhor, K.J.; Bindu, J. (2010). Synthesis, characterization and evaluation of antibacterial and antifungal activity of triazole derivatives of gallic acid. Inter. J. Applied Bio. and Pharm. Tech., I,1300-1321. 